\title{
The Impact of Bank Income Diversification on Capital Buffer Periodicity
}

\author{
Yu Wang \\ Department of Finance, Jinan University, Guangzhou, China \\ Email:vavierwang@foxmail.com
}

How to cite this paper: Wang, Y. (2017) The Impact of Bank Income Diversification on Capital Buffer Periodicity. Open Journal of Business and Management, 5, 388-400. https://doi.org/10.4236/ojbm.2017.52033

Received: February 23, 2017

Accepted: April 27, 2017

Published: April 30, 2017

Copyright $\odot 2017$ by author and Scientific Research Publishing Inc. This work is licensed under the Creative Commons Attribution International License (CC BY 4.0).

http://creativecommons.org/licenses/by/4.0/

\begin{abstract}
Based on the panel data of 16 listed banks in China from 2004 to 2014, this paper makes empirical analysis to examine the relationship between bank's capital buffer and macroeconomic fluctuations or income diversification. The results show that the banks' income diversification has negatively correlation with macroeconomic fluctuations. It means the banks' capital buffer behaves in a counter-cyclical way, and different bank ownership structure or capital level also has asymmetric influence in expansion and slack time. What's more, the non-interest income of bank has a significant negative impact on capital buffer and its periodicity. The diversification of bank income structure not only reduces the bank's capital buffer level, but also weakens the counter-cyclical characteristics of capital buffer. At the same time, the diversification of the income structure of the bank with high capital adequacy ratio has no obvious effect on the counter-cyclical characteristics of the capital buffer. Based on the above conclusions, this paper believes that the regulatory authorities in the implementation of the counter-cyclical capital regulation should fully consider the impact of bank income structure and bank capital levels.
\end{abstract}

\section{Keywords}

Macroeconomic Fluctuations, Income Diversification, Capital Buffer

\section{Introduction}

The global financial crisis in 2008 exposed many problems of current financial regulation system, especially the procyclicality of bank regulation, which, with the increased economic fluctuations, not only made the bank itself became more risky, but also amplified the impact of prosperity and recession in the economic cycle, further exacerbated the turmoil in the financial system, and ultimately affected the banking system and macro financial stability. By the end of 2010, the author of Basel agreement III proposed the counter-cyclical capital buffer as one 
of the measures to strengthen macro prudential regulation, in order to improve the stability of the macroeconomic and financial system. However, there was still not a unified conclusion on the cyclicity of the capital buffer in the academia; capital buffer had procyclical characteristics in their empirical study, while some other studies had suggested that the capital buffer was prone to be counter cyclical [1].

Among the domestic researches, most of them focus on examining the cyclical characteristics of the capital buffer and its relations with the growth rate of bank lending and the risk-taking as well; while there is little research on the impact of the revenue structure of the bank on the cyclicity of the capital buffer. In recent years, due to the intense inter-bank competition intensified by the financial disintermediation and interest rate marketization, and the narrowing of interest rate spread, the banking business mode has changed greatly striving to develop intermediary services to increase the non-interest income's proportion in the revenue. How will the diversified revenue structure of the bank with greater proportion of non-interest income affect the capital buffer? What are the impacts on the cyclicity of the capital buffer? Thus this paper attempts an analysis of the relationship between the revenue diversification of the bank and capital buffer s introducing in the diversified revenue structure indices. Moreover, with the introduction of the cross terms of revenue structure and economic cycle, we research on the impact of revenue structure on the cyclicity of the capital buffer that is where the innovation of this paper lies. Unfortunately, most Chinese scholars focus on the impacts of revenue diversification on the risk-taking and the bank's performance. Besides, it is also of great significance to improve the effectiveness of macro prudential supervision and develop the bank's intermediary services in the new regulatory and market circumstances by researching on the relationships between revenue diversification, macroeconomic fluctuations and capital buffers.

\section{Literature Review}

There is yet no consistent conclusion about the cyclicity of capital buffer in the empirical examination. Ayuso was the first person who empirically tested it by analyzing the data from the Spanish commercial and savings banks during 1986-2000, and the result showed that the capital buffer in the Bank of Spain is Pro-cyclical, which was more significant in the upward period of the economic cycle [2]. Because in the upward period, the bank underestimates the risk level, held a lower capital buffer and expanded the scale of loans in the pursuit of profit. While in the downward period, the default rate and the risk increased and it was hard to replenish capital, but in order to meet the regulatory minimum capital requirement, banks would reduce loans through the reduction of risk weighted assets to increase capital buffer. Thus the behavior of the bank's capital buffer was pro-cyclical. On the basis of Ayuso's research, Lindquist found that bank capital buffer was positively related to capital buffer of their competitors and the pro-cyclicality of the capital buffers in banks with low capital adequacy 
was more significant by analyzing empirically the quarterly data of Norway's banking during 1995-2001. Tabak et al. showed that there was a significant negative correlation between the capital buffer and the economic cycle in Brazil, based on the study of the unbalanced panel data of the Brazil banking in 20002010. Coffinet et al., Shim found that the capital buffer behavior of the banks in France and the United States is also pro-cyclical. However, Jokipii and Milne conducted an empirical test by making use of the data from 468 European banks and savings institutions during 1997-2004 and the result showed that the capital buffer behavior of EU15 bank was pro-cyclical while that of RAM10 bank was counter cyclical. Cyclicity of the capital buffer of the European banking was related to the size and type of the bank. Capital buffer of the commercial bank and savings bank was procyclical, while cooperative bank's capital buffers was counter cyclical; big bank's capital buffer was procyclical, while small bank's was counter cyclical. Fonseca and Gonzalez found that the capital buffer in 5 out of 70 countries worldwide was positively related to the economic cycle while the capital buffer in 7 out of those 70 countries was negatively correlated to the economic cycle, and the capital buffers in other 59 countries were not significantly related to the economic cycle. Carvallo etc. have found that Argentina, Colombia, Ecuador, Peru and Uruguay, the five countries banking capital buffer was pro-cyclical, based on 13 non-balanced panel data for banking in Latin America and the Caribbean in 2001-2012, that Bolivia, Brazil, the Dominican republic, Mexico, Panama, Venezuela banking capital buffers is counter-cyclical, that Chile and Paraguay's banking capital buffers that there was no significant correlation with the economic fluctuation. Guidara et al. found that Canadian banking capital buffering was counter-cyclical using the empirical study of Canadian quarterly data from 1982 to 2010.

Domestic scholars have not reached a conclusive conclusion on the study of capital buffer cycle problems. Liu Bin found that China's 16 commercial banks capital adequacy ratio were negatively related with the GDP growth rate, that was pro-cyclical. Li Wenhong and Luo Meng used the data of 16 Chinese commercial banks from 1998 to 2008, and found that the capital adequacy ratio of China's commercial banks had a certain procyclicality. Zhang Jincheng and $\mathrm{Li}$ Cheng also came to the same conclusion. Zhang Jincheng and Li Cheng also reached the same conclusion. But our country banking capital buffers as a whole was not cyclical, but the five state-owned banks Capital buffering behavior was counter-cyclical, and the capital buffering behavior of joint-stock banks, urban commercial banks and rural commercial banks had no obvious cyclical characteristics based on the data of 89 commercial banks in China from 1997 to 2010 using differential GMM method [3]. Zhang Zongxin and Xu Bingyu Based on the panel data of China's listed banks from 2002 to 2009, found that the capital buffer of listed banks in China was positively correlated with the output gap, that the capital buffer behavior was counter-cyclical. Jiang Hai et al. conducted an empirical study using the annual data of 16 Chinese listed banks from 1998 to 2011. The results showed that the capital buffer of listed banks in China had sig- 
nificant counter-cyclicality, and the implementation of the Basel Capital Accord The policy reinforced the countercyclicality of capital buffers.

In addition to the structure of bank ownership, market competition, capital level, regulatory policy and other factors, the bank's income structure will also affect the bank capital buffer behavior to a certain extent [4]. Li Haihong, Hu Jin believed that the faster the capital buffer added and the higher the degree of diversification of banks obtained, the risk of the portfolio was hedged to a certain extent based on the data of all listed banks in 2007-2012 by using the simultaneous equation method. At present, the literature on the diversification of bank income is more related to risk, business performance. Lepetit empirical study shows that non-interest income increased bank risk, while transaction-based business was less relevant than service-related business and risk. Wang Jing argued that while the growth of non-interest income increased the bank's earnings, higher non-interest income fluctuations offseted the gains and thus lowered bank performance. The increase in non-interest income of banks had increased the risk of banks, and the correlation between interest income and non-interest income had reduced the risk of diversification in the portfolio [5]. Wang Manshu et al. analyzed the quarterly panel data of 14 listed banks from 2008 to 2010, and found that diversification of income increased the bank's profitability, mainly due to the fixed cost of intermediate business, not only to expand its business scope.

\section{Empirical Research Design}

\subsection{Model Setting}

1) Capital buffer and economic cycle relationship model setting

The following measurement benchmark model was constructed using the study of Ayuso and Joppiki \& Milne

$$
B U F_{i t}=\alpha_{0} B U F_{i, t-1}+\alpha_{1} G D P G_{t}+\alpha_{2} H H I_{t}+\alpha_{3} \ln \text { size }+\alpha_{4} N P L+\alpha_{5} R O A
$$

On the basis of the benchmark model, in order to test the asymmetric effects of macroeconomic fluctuations on the economic expansion and recession, we refer to Stoltz and Wedoe to introduce up and down dummy variables, which are multiplied by economic fluctuation variables from cross items, The model are as follows:

$$
\begin{aligned}
B U F_{i t}= & \alpha_{0} B U F_{i, t-1}+\alpha_{1} G D P G_{t}^{*} u p+\alpha_{2} G D P G_{t}^{*} \text { down }+\alpha_{3} H H I_{t} \\
& +\alpha_{4} \ln \text { size }+\alpha_{5} N P L+\alpha_{6} R O A \\
B U F_{i t}= & \alpha_{0} B U F_{i, t-1}+\alpha_{1} G D P G_{t} * \text { up } * \text { state }+\alpha_{2} G D P G_{t} * \text { down } * \text { state } \\
+ & \alpha_{3} G D P G_{t} * \text { up } * \text { stock }+\alpha_{4} G D P G_{t} * \text { down } * \text { stock }+\alpha_{5} H H I_{t} \\
& +\alpha_{6} \ln \text { size }+\alpha_{7} N P L+\alpha_{8} R O A
\end{aligned}
$$

To determine whether the difference between bank ownership and capital level has an impact on capital buffering and macroeconomic volatility, we establish the following model: 


$$
\begin{aligned}
B U F_{i t}= & \alpha_{0} B U F_{i, t-1}+\alpha_{1} G D P G_{t} * u p * H+\alpha_{2} G D P G_{t} * \text { down } * H+\alpha_{3} G D P G_{t} * u p * L \\
& +\alpha_{4} G D P G_{t} * \text { down } * L+\alpha_{5} H H I_{t}+\alpha_{6} \ln \text { size }+\alpha_{7} N P L+\alpha_{8} R O A
\end{aligned}
$$

Up as economic expansion virtual variables, when GDP gap is larger than 0 , the up takes 1; Down as recession virtual variables, when GDP gap less than zero, down takes 1 .

2) The impact of the diversification of income on the cyclical nature of capital buffer

The introduction of economic growth and diversification of bank income GDPG ${ }^{*} \mathrm{HHI}$ in the model to further study whether the bank's income structure has affected the cyclical characteristics of capital buffer.

In order to verify the impact of the diversification of bank income diversification on the capital buffer cycle, the following models are established:

$$
\begin{gathered}
\text { BUF } F_{i t}=\alpha_{0} B U F_{i, t-1}+\alpha_{1} G D P G_{t}+\alpha_{2} H H I_{t}+\alpha_{3} H+\alpha_{4} G D P G * H H I * H \\
+\alpha_{5} \ln \text { size }+\alpha_{6} N P L+\alpha_{7} R O A \\
B U F_{i t}= \\
\alpha_{0} B U F_{i, t-1}+\alpha_{1} G D P G_{t} * u p * H+\alpha_{2} G D P G_{t} * \text { down } * H+\alpha_{3} G D P G_{t} * u p * L \\
+\alpha_{4} G D P G_{t} * \text { down } * L+\alpha_{5} H H I_{t}+\alpha_{6} \ln \text { size }+\alpha_{7} N P L+\alpha_{8} R O A
\end{gathered}
$$

\subsection{The Main Explanation Variable Description}

- Income Diversification

Existing in the study, the bank income structure variables can be measured in non-interest income ratio or the opposite of the Herfindahl-Hirschman index (HHI), each subclass income divided by the square sum of square of total revenue. This paper uses the net interest income as a percentage of operating income (IN) and non-interest income as a percentage of operating income (NONIN). The formula is $\mathrm{DIV}=1-\mathrm{IN}^{2}-\mathrm{NONIN}^{2}$. The greater is the DIV value, the higher is the degree of bank diversification. The The high degree of diversification of income structure will reduce the volatility of bank profits, thereby reducing the bank's operating risks, prompting banks to retain less capital buffers to resist liquidity and bankruptcy risks. Diversified income diversities are expected to be negatively correlated with bank capital buffers relationship.

- Bank Size. Large

Banks have a wide range of operations, strong overall strength, low income volatility, and easy access to capital in the capital markets. According to the argument "big can not fall", the big banks in the financial crisis is more likely to obtain relief, reducing the motivation of capital holdings. In this paper, the natural logarithm of the total assets to indicate the size of the bank, is expected to have a negative correlation with the capital buffer.

- Profitability

Bank's external financing costs are often higher than internal financing. The premise of internal financing is the bank's profitability. The higher the total assets of yields, explaining the bank's profit is higher, sufficient profits retained to ensure the supply of capital. And internal retained profits is an important approach to increase capital buffers. This paper uses the average return on assets 
(ROA) to measure the profitability of commercial banks.

- NPL Ratio

The non-performing loan ratio is an aftermath risk measure, which is an alternative indicator of bank asset quality and bank risk. The higher the NPL ratio, the more likely it is to erode the capital level of the bank and reduce the capital buffer, so the expected symbol is negative.

- Dummy variables $\mathrm{H}$ and dummy variables $\mathrm{L}$

Stolz and Wedow's empirical study on the west bank found that banks with different capital adequacy levels responded to macroeconomic fluctuations differently. In accordance with the provisions of our regulatory authorities, the capital buffer is higher than $2 \%$ of the banks classified as a class with the dummy variable $\mathrm{L}$, the capital buffer higher than $2 \%$ of the banks classified as a class, with the dummy variable $\mathrm{H}$.

- Dummy variables State and dummy variables Stock

State-owned banks such as Industrial and Commercial Bank of China, Agricultural Bank of China, China Bank, China Construction Bank, Bank of Communications, are classified as State class, the other 11 banks such as Huaxia Bank, Everbright Bank classified as a class.

\subsection{Sample Data}

During the sample period, the average capital adequacy of listed banks was $3.31 \%$, indicating that the average capital adequacy ratio of 16 listed banks reached $11.31 \%$, much higher than the minimum regulatory standard of Basel III. Minimum and maximum value appeared in 2005 respectively Everbright Bank and Bank of Nanjing in 2007. The standard deviation of capital buffer is 3.312 , indicating that the capital buffer held by the sample is quite different. The average income of the banks was $25.6 \%$, and the income of Nanjing Bank in 2004 was negative, mainly due to loss of investment, fair value and loreign exchange. Ping An Bank in 2004 accounted for the largest proportion of income diversification, up to $49.7 \%$.

Figure 1 describes the average capital buffers, average core capital buffers and the income diversity change with the economic cycle of the sample Banks since 2004. As the sample period covers the upward and downward periods of the economy, it can be used to analyze the behavioral differences of banks under

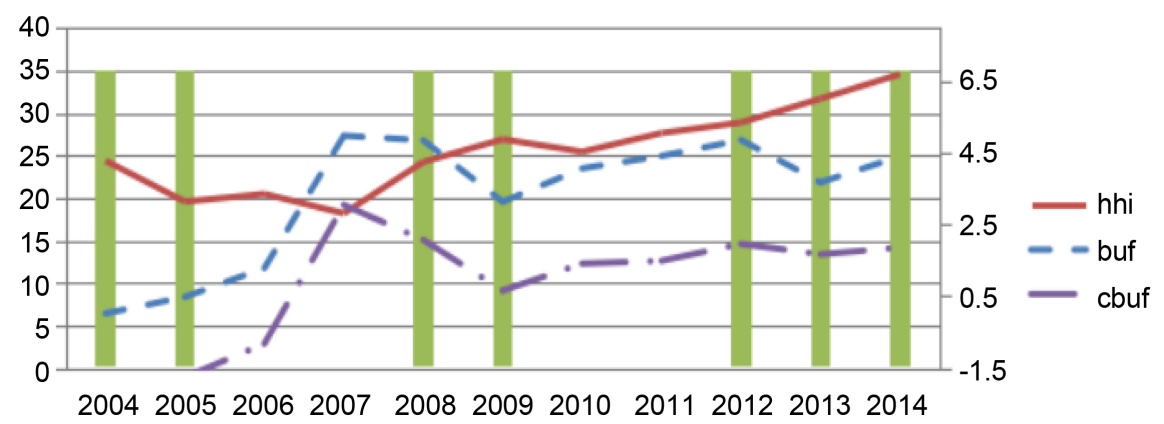

Figure 1. Macroeconomic fluctuations, income diversification and capital buffer. 
different macroeconomic conditions. As can be seen from the figure, in the economic upside, such as 2006, 2007, capital buffer and core capital buffer increased, and to the economic downturn, such as 2012 to 2014, capital buffer and core Capital buffer declined. It is possible to determine that capital buffer and the core capital buffer may have a positive correlation with the economic cycle. In addition, it can be seen from the figure that the capital buffer has a clear negative correlation with the bank's income diversification.

\subsection{Estimation Method}

Since the econometric model in this paper contains the lag explanatory variables of the first order, and other explanatory variables such as GDP growth may have endogenous problems relative to the explanatory variable capital buffers. For the dendogenous variables and sample heterogeneity problem existing in the deviation of estimated dynamic panel data, GMM estimation uses differential and tool variables to control unrecognized time or individual effects, and solves the endogenous problems caused by the two-way causality using the lagged first-order explanatory variables and the previous explanatory variables as tool variables.

\section{Empirical Analysis}

\subsection{The Relations of Capital Buffer and Economic Cycle}

Capital buffers have a counter-cyclical characteristics. It can be seen from Table 1 that the first-order coefficients of the explanatory variable capital buffer and the core capital buffer are significantly positive, which indicates that the capital buffer and the core capital buffer are dynamically continuous. The current value is highly correlated with the previous value, indicating the rationality of using the dynamic panel. At the same time, it can be seen that the capital buffer of our listed banks is positively correlated with the core capital buffer and the economic cycle. Both the capital buffer and the core capital buffer are counter-cyclical, that is, during the economic upturn, banks to increase capital buffer, in the economic downturn, reduce capital buffer [2]. Bank diversification of income structure generally reduce the level of bank capital buffer. In column 1) of Table 1, the DIV is significantly negative at the $5 \%$ confidence level. Fourth column shows that the income structure diversification has a negative correlation with the core capital buffer at a $1 \%$ confidence level. This suggests that bank diversification of income structure makes banks tend to hold less capital buffers (Li Haihong, 2014; Meng Weidong, 2014). In the current situation of non-interest income of commercial banks in China not high, the income diversification can effectively reduce the risk of asset portfolio dispersion, improving the risk adjustment return. The existing capital retention can be appropriately reduced, banks do not need to hold more capital buffer to face the pressure of supervision.

In column (2) of Table 1, the virtual variables of State state-owned Banks and economic growth nteraction coefficient is negative in the $10 \%$ significant level. In column (3), the coefficient of the interaction between the dummy variable of the joint-stock bank and economic growth is positive at the significant level of 
Table 1. The impact of macroeconomic fluctuation and income diversification on capital buffer.

\begin{tabular}{|c|c|c|c|c|c|c|}
\hline & (1) & (2) & (3) & (4) & (5) & (6) \\
\hline & buf & buf & buf & cbuf & cbuf & cbuf \\
\hline \multirow[t]{2}{*}{ L.buf } & $0.364^{\star *}$ & $0.301^{*}$ & $0.301^{*}$ & & & \\
\hline & $(2.33)$ & $(1.79)$ & $(1.79)$ & & & \\
\hline \multirow[t]{2}{*}{ L.cbuf } & & & & $0.437^{\star * *}$ & $0.356^{* * *}$ & $0.356^{\star * *}$ \\
\hline & & & & $(2.69)$ & $(4.07)$ & $(4.07)$ \\
\hline \multirow[t]{2}{*}{ GDPG } & $0.130^{* * *}$ & $0.159^{* * *}$ & -0.0136 & $0.119^{\star *}$ & $0.114^{\star \star}$ & 0.00478 \\
\hline & $(2.79)$ & $(2.70)$ & $(-0.18)$ & $(2.51)$ & $(2.12)$ & $(0.07)$ \\
\hline \multirow[t]{2}{*}{ HHI } & $-6.490^{* *}$ & $-6.025^{\star *}$ & $-6.025^{\star *}$ & $-8.183^{* * *}$ & $-8.128^{* * *}$ & $-8.128^{\star * \star}$ \\
\hline & $(-2.46)$ & $(-2.32)$ & $(-2.32)$ & $(-2.91)$ & $(-3.22)$ & $(-3.22)$ \\
\hline \multirow[t]{2}{*}{ lnsize } & 0.118 & -0.390 & -0.390 & 0.148 & -0.343 & -0.343 \\
\hline & $(0.67)$ & $(-1.32)$ & $(-1.32)$ & $(0.82)$ & $(-1.54)$ & $(-1.54)$ \\
\hline \multirow[t]{2}{*}{ roa } & $3.080^{* *}$ & $3.504^{* * *}$ & $3.504^{* * *}$ & $3.456^{* *}$ & $3.613^{* * *}$ & $3.613^{* * *}$ \\
\hline & $(2.48)$ & $(2.76)$ & $(2.76)$ & $(2.57)$ & $(3.59)$ & $(3.59)$ \\
\hline \multirow[t]{2}{*}{$\mathrm{npl}$} & $-0.186^{* * *}$ & $-0.222^{\star * *}$ & $-0.222^{\star * *}$ & -0.143 & $-0.320^{\star *}$ & $-0.320^{\star *}$ \\
\hline & $(-2.68)$ & $(-2.86)$ & $(-2.86)$ & $(-0.91)$ & $(-1.99)$ & $(-1.99)$ \\
\hline \multirow[t]{2}{*}{ STATE } & & $4.351^{* * *}$ & & & $3.379^{* * *}$ & \\
\hline & & $(3.48)$ & & & $(2.71)$ & \\
\hline \multirow[t]{2}{*}{ STATE_GDPG } & & $-0.173^{\star}$ & & & -0.137 & \\
\hline & & $(-1.90)$ & & & $(-1.46)$ & \\
\hline \multirow[t]{2}{*}{ STOCK } & & & $-4.351^{\star * *}$ & & & $-3.379^{* * *}$ \\
\hline & & & $(-3.48)$ & & & $(-2.71)$ \\
\hline \multirow[t]{2}{*}{ STOCK_GDPG } & & & $0.173^{*}$ & & & 0.109 \\
\hline & & & $(1.90)$ & & & $(1.23)$ \\
\hline \multirow[t]{2}{*}{ _cons } & -1.544 & 2.119 & $6.470^{* *}$ & $-3.474^{\star \star}$ & 0.968 & 4.347 \\
\hline & $(-1.02)$ & $(0.81)$ & $(2.17)$ & $(-2.20)$ & $(0.43)$ & $(1.64)$ \\
\hline$A R(2)$ & 0.158 & 0.176 & 0.176 & 0.200 & 0.246 & 0.246 \\
\hline$S A R G A N$ & 0.317 & 0.252 & 0.252 & 0.693 & 0.530 & 0.530 \\
\hline
\end{tabular}

$10 \%$, and In the group of results that the explanatory variable is the core capital buffer, the interaction coefficient of the state-owned bank's dummy variable State and the economic growth GDPG is negative. The interaction variable of the joint-stock bank with the economic growth GDPG is positive, but not significant. Indicating that the counter-cyclical nature of state-owned banks' capital buffers will be weaker than that of joint-stock banks. In column (5), The interaction variable of the joint-stock bank with the economic growth GDPG is positive, but not significant, indicating that the counter-cyclical nature of stateowned banks' capital buffers would be weaker than that of joint-stock banks.

The effect of other control variables on capital buffering. Roa's coefficient is significantly positive at the $5 \%$ confidence level, indicating that the higher the yield on bank assets, the easier it is to replenish capital by retaining earnings to 
raise capital buffer levels. $\mathrm{Npl}$ and capital buffer are negatively correlated with the $1 \%$ confidence level, which is negatively correlated with the core capital buffer but not significantly, indicating that reducing the risk level of the bank is conducive to the accumulation of capital buffer, which is in accordance with the theoretical expectation.

\subsection{The Regression Results of Different Ownership, Capital Buffer Level}

In column (1) of Table 2, the buf* GDPG* ${ }^{\star}$ P coefficient is positive at the $5 \%$ significance level, and the buf ${ }^{\star} \mathrm{GDPG}^{\star} \mathrm{DOWN}$ coefficient is also significantly positive at the $10 \%$ significance level, which show that the capital buffer is counter-cyclical in both the up and down periods of the economy, and the inverse period of the upside is stronger than that of the downside. In the upside, the bank's capital level is relatively high. But in the downside, due to increased loan default risk, the bank's profit decline has reduced the bank's retained profits and raised the bank's external capital costs. Thus banks would reduce risk-weighted assets by reducing loans and reducing bank credit risk, resulting in a relative increase in capital buffers. In column (2), cbuf* GDPG ${ }^{\star}$ up is positive at $10 \%$ significant level, and cbuf $^{\star} \mathrm{GDPG}^{\star}$ down is positive, but not significant, indicating that the core capital buffer only in the economic upfront period is counter-cyclical, and in the economic downturn is weakly cyclical.

In Table 2, column (2), GDPG ${ }^{\star} \mathrm{up}^{\star} \mathrm{L}$ and $\mathrm{GDPG}^{\star}{ }^{*} \mathrm{down}^{\star} \mathrm{L}$ coefficients are positive at a significant level of $1 \%$, indicating that low capital banks in the economy upward and downward periods of capital buffers have an inverse cyclical. In the meantime, GDPG ${ }^{*} \mathrm{up}^{\star} \mathrm{H}$ was positive at $5 \%$ significant level, the coefficient of GDPG $^{\star}$ down $^{\star} \mathrm{H}$ was positive but not significant, suggesting that banks with high capital levels will increase their capital buffers when the economy is on the rise and the decline of capital cushion is not obvious in the recession under the combined effect of bank capital reduction and credit crunch. Banks of low-capital are looking forward to increasing capital shocks when the economy is on track to prevent capital buffers from falling to the minimum capital requirements and facing regulatory penalties when the economy is down. In the economic downturn, the reduction of capital and the initiative to increase the loan loss and the superposition of factors eventually lead to a substantial adjustment of capital buffer level. As can be seen from the results, the response to the economic cycle of banks with different capital levels is mainly reflected in the economic downturn. As can be seen from column (5) of Table 2, banks with low capital levels will increase their core capital buffers during the upswing period and reduce core capital buffers during a recession. However, for the high capital level banks, the core cyclical characteristics of the core capital buffer are not obvious.

In column (3) of Table 2 , GDPG* ${ }^{\star} p^{*}$ state the GDPG* Down ${ }^{*}$ state are significantly positive at $5 \%$ confidence level, indicating that the capital buffer of the state-owned banks is counter-cyclical in the economic upside and downside. We also notice the fact that $\mathrm{GDPG}^{*} \mathrm{Up}^{\star}$ Stock coefficient is significantly positive at 
Table 2. The return results of different ownership, capital buffer level of banks.

\begin{tabular}{|c|c|c|c|c|c|c|}
\hline & (1) & (2) & (3) & (4) & (5) & (6) \\
\hline & buf & buf & buf & cbuf & cbuf & cbuf \\
\hline \multirow[t]{2}{*}{ L.buf } & $0.372^{* *}$ & $0.386^{* *}$ & $0.478^{* *}$ & & & \\
\hline & $(2.17)$ & $(2.31)$ & $(2.16)$ & & & \\
\hline \multirow[t]{2}{*}{ L.cbuf } & & & & $0.489^{* * *}$ & $0.482^{* * *}$ & $0.519^{* * *}$ \\
\hline & & & & $(2.66)$ & $(2.73)$ & $(2.58)$ \\
\hline \multirow[t]{2}{*}{$\mathrm{GDPG}^{*} \mathrm{Up}$} & $0.128^{* *}$ & & & $0.0967^{*}$ & & \\
\hline & $(2.53)$ & & & $(1.82)$ & & \\
\hline \multirow[t]{2}{*}{ GDPG $^{\star}$ Down } & $0.123^{*}$ & & & 0.0602 & & \\
\hline & $(1.76)$ & & & $(0.78)$ & & \\
\hline \multirow[t]{2}{*}{ hhi } & $-6.548^{* *}$ & $-5.939^{* *}$ & $-7.050^{* *}$ & $-8.332^{* * *}$ & $-8.204^{* * *}$ & $-7.815^{* * *}$ \\
\hline & $(-2.43)$ & $(-2.30)$ & $(-2.48)$ & $(-2.89)$ & $(-2.95)$ & $(-2.84)$ \\
\hline \multirow[t]{2}{*}{ lnsize } & 0.120 & 0.246 & 0.0375 & 0.146 & 0.338 & 0.155 \\
\hline & $(0.67)$ & $(1.19)$ & $(0.11)$ & $(0.79)$ & $(1.58)$ & $(0.46)$ \\
\hline \multirow[t]{2}{*}{ roa } & $3.038^{* *}$ & $3.622^{* * *}$ & 2.348 & $3.209^{* *}$ & $3.789^{* * *}$ & $2.739^{*}$ \\
\hline & $(2.30)$ & $(2.95)$ & $(1.48)$ & $(2.23)$ & $(2.76)$ & $(1.85)$ \\
\hline \multirow[t]{2}{*}{$\mathrm{npl}$} & $-0.184^{* * *}$ & $-0.220^{* * *}$ & $-0.170^{*}$ & -0.105 & -0.220 & -0.142 \\
\hline & $(-2.59)$ & $(-3.16)$ & $(-1.91)$ & $(-0.63)$ & $(-1.33)$ & $(-0.74)$ \\
\hline \multirow[t]{2}{*}{$\mathrm{GDPG}^{\star} \mathrm{Up}^{\star} \mathrm{H}$} & & $0.104^{\star *}$ & & & 0.0813 & \\
\hline & & $(2.02)$ & & & $(1.53)$ & \\
\hline \multirow[t]{2}{*}{$\mathrm{GDPG}^{\star} \mathrm{Up}^{\star} \mathrm{L}$} & & $0.185^{\star * *}$ & & & $0.200^{\star * *}$ & \\
\hline & & $(2.76)$ & & & $(2.87)$ & \\
\hline \multirow[t]{2}{*}{$\mathrm{GDPG}^{\star}$ Down $^{\star} \mathrm{H}$} & & 0.0788 & & & 0.0485 & \\
\hline & & $(1.01)$ & & & $(0.60)$ & \\
\hline \multirow{2}{*}{ GDPG $^{\star}$ Down $^{\star} \mathrm{L}$} & & $0.193^{* * *}$ & & & $0.155^{* *}$ & \\
\hline & & $(2.64)$ & & & $(1.98)$ & \\
\hline \multirow[t]{2}{*}{$\mathrm{GDPG}^{\star} \mathrm{Up}^{\star}$ State } & & & $0.173^{* *}$ & & & $0.209^{* *}$ \\
\hline & & & $(2.09)$ & & & $(2.55)$ \\
\hline \multirow[t]{2}{*}{ GDPG $^{\star}$ Down $^{\star}$ State } & & & $0.236^{* *}$ & & & $0.290^{* *}$ \\
\hline & & & $(2.05)$ & & & $(2.43)$ \\
\hline \multirow[t]{2}{*}{$\mathrm{GDPG}^{*} \mathrm{Up}^{\star}$ Stock } & & & $0.173^{*}$ & & & $0.234^{\star *}$ \\
\hline & & & $(1.71)$ & & & $(2.41)$ \\
\hline \multirow[t]{2}{*}{ GDPG $^{\star}$ Down $^{\star}$ Stock } & & & 1.878 & & & $2.866^{*}$ \\
\hline & & & $(1.19)$ & & & $(1.88)$ \\
\hline \multirow[t]{2}{*}{ _cons } & -1.469 & $-3.300^{*}$ & -0.951 & -2.722 & $-5.204^{* * *}$ & -4.689 \\
\hline & $(-0.91)$ & $(-1.75)$ & $(-0.27)$ & $(-1.50)$ & $(-2.75)$ & $(-1.41)$ \\
\hline$A R(2)$ & 0.165 & 0.195 & 0.131 & 0.215 & 0.229 & 0.102 \\
\hline$S A R G A N$ & 0.312 & 0.447 & 0.159 & 0.856 & 0.671 & 0.591 \\
\hline
\end{tabular}

$10 \%$ level, GDPG ${ }^{\star}$ Down ${ }^{\star}$ Stock coefficient is positive but not obvious, which indicates that the joint-stock banks will increase the capital buffer in the economy up and the countercyclical character of capital buffering is not obvious in the economic recession. The possible reason is that during a recession, joint-stock banks are less likely to have state bailouts as state-owned banks, so they are faced with high cost of financing in the capital markets. Therefore, in order to prevent 
the capital adequacy ratio being lower than the minimum capital regulation requirements, it is easier for joint-stock banks to use the retained earnings in the economy when the increase in capital buffer. As can be seen in Table 2 (6), the core capital buffers of joint-stock and state-owned banks are counter-cyclical no matter the economy is in the uptrend or downside.

\subsection{The Relations of Capital Buffer, Economic Cycle, Income Diversification}

The results in column (1) and column (4) of Table 3 show that the coefficients of GDPG*HHI are significantly negative in the capital buffer equation, suggest-

Table 3. Income diversification and capital buffer cyclical behavior.

\begin{tabular}{|c|c|c|c|c|c|c|}
\hline & (1) & (2) & (3) & (4) & (5) & (6) \\
\hline & buf & buf & buf & cbuf & cbuf & cbuf \\
\hline \multirow[t]{2}{*}{ L.buf } & $0.562^{* * *}$ & $0.381^{* *}$ & $0.368^{* *}$ & & & \\
\hline & $(3.51)$ & $(2.56)$ & $(2.50)$ & & & \\
\hline \multirow[t]{2}{*}{ L.cbuf } & & & & $0.518^{\star * *}$ & $0.432^{\star * *}$ & $0.437^{\star * *}$ \\
\hline & & & & $(3.48)$ & $(2.74)$ & $(2.83)$ \\
\hline \multirow[t]{2}{*}{ GDPG } & $0.176^{\star * *}$ & $0.240^{* * *}$ & $0.173^{* * *}$ & $0.145^{\star * *}$ & $0.198^{* *}$ & $0.183^{* * *}$ \\
\hline & $(3.96)$ & $(3.16)$ & $(3.49)$ & $(3.44)$ & $(2.52)$ & $(3.66)$ \\
\hline \multirow[t]{2}{*}{$\mathrm{HHI}$} & $-4.280^{*}$ & -1.899 & -1.372 & $-5.255^{\star *}$ & -4.798 & -1.532 \\
\hline & $(-1.79)$ & $(-0.57)$ & $(-0.45)$ & $(-2.18)$ & $(-1.30)$ & $(-0.49)$ \\
\hline \multirow[t]{2}{*}{$\mathrm{GDPG}^{*} \mathrm{HHI}$} & $-3.036^{* * *}$ & & & $-2.935^{* * *}$ & & \\
\hline & $(-5.90)$ & & & $(-6.18)$ & & \\
\hline \multirow[t]{2}{*}{ lnsize } & 0.100 & 0.259 & 0.0910 & 0.0335 & 0.274 & 0.0867 \\
\hline & $(0.62)$ & $(1.29)$ & $(0.47)$ & $(0.22)$ & $(1.29)$ & $(0.43)$ \\
\hline \multirow[t]{2}{*}{ roa } & 1.152 & $3.696^{* * *}$ & $2.761^{* *}$ & $2.433^{*}$ & $4.074^{\star * *}$ & $2.805^{\star *}$ \\
\hline & $(0.89)$ & $(3.26)$ & $(2.28)$ & $(1.94)$ & $(3.24)$ & $(2.12)$ \\
\hline \multirow[t]{2}{*}{$\mathrm{npl}$} & $-0.169^{* * *}$ & $-0.246^{* * *}$ & $-0.162^{\star *}$ & -0.132 & -0.182 & -0.207 \\
\hline & $(-2.61)$ & $(-3.49)$ & $(-2.23)$ & $(-0.95)$ & $(-1.16)$ & $(-1.34)$ \\
\hline \multirow[t]{2}{*}{$\mathrm{H}$} & & 0.556 & & & 0.189 & \\
\hline & & $(0.57)$ & & & $(0.18)$ & \\
\hline \multirow[t]{2}{*}{$\mathrm{L}$} & & & $2.519^{* *}$ & & & $3.370^{* * *}$ \\
\hline & & & $(2.41)$ & & & $(3.09)$ \\
\hline \multirow[t]{2}{*}{$\mathrm{GDPG}^{\star} \mathrm{HHI}^{\star} \mathrm{H}$} & & $-0.535^{\star}$ & & & -0.386 & \\
\hline & & $(-1.88)$ & & & $(-1.30)$ & \\
\hline \multirow[t]{2}{*}{$\mathrm{GDPG}^{\star} \mathrm{HHI}^{\star} \mathrm{L}$} & & & $-0.676^{\star *}$ & & & $-0.988^{\star * *}$ \\
\hline & & & $(-2.23)$ & & & $(-3.16)$ \\
\hline \multirow[t]{2}{*}{ _cons } & -1.746 & $-5.179^{\star *}$ & -3.015 & $-2.984^{* *}$ & $-6.310^{* * *}$ & $-4.784^{\star *}$ \\
\hline & $(-1.24)$ & $(-2.19)$ & $(-1.56)$ & $(-2.15)$ & $(-2.60)$ & $(-2.56)$ \\
\hline$A R(2)$ & 0.305 & 0.149 & 0.268 & 0.252 & 0.184 & 0.329 \\
\hline$S A R G A N$ & 0.740 & 0.379 & 0.588 & 0.142 & 0.652 & 0.242 \\
\hline
\end{tabular}


ing that there is a strong positive correlation between the level of capital buffer and the core capital buffer level with the economic cycle for banks with weak trend of diversification of income structure, and the diversification of bank income weakens the counter-cyclical nature of capital buffering and core capital buffering. During the upswing of the economy, banks are generally optimistic about the outlook for the economy, while the diversification of income structure has increased the income of intermediary business, the possibility of nonperforming loan default risk is small, the increase in revenue is fast, and the bank retains less capital buffer. All these facts weaken the positive correlation between capital buffer and economic cycle. The estimated coefficient of GDPG ${ }^{\star} \mathrm{HHI}^{\star} \mathrm{H}$ in the (2) column is negative at a significant level of $10 \%$, and the estimated value of $\mathrm{GDPG}^{\star} \mathrm{HHI}^{\star} \mathrm{L}$ in column (3) is negative at a significant level of $5 \%$, indicating that the role of income diversification in weakening the counter-cyclical nature of capital buffers is more pronounced for banks with lower capital adequacy levels than in high capital adequacy levels. The estimated coefficient of $\mathrm{GDPG}^{\star} \mathrm{HHI}^{\star} \mathrm{H}$ in column (5) is positive but not significant, and the estimated coefficient of $\mathrm{GDPG}^{\star} \mathrm{HHI}^{\star} \mathrm{L}$ in column (6) is significantly negative, indicating the diversification of income structure is not obvious in weakening the counter-economical character of core capital buffers for a bank with a high capital adequacy ratio.

\section{Robustness Test}

To ensure the reliability of the empirical analysis of this paper by excluding the possibility of biasing the system GMM estimates under limited samples, in this paper, we use the rule of law of Bond et al. (2002) to estimate the OLS and fix the effect of the above 18 equations. The lagged term of the explanatory variable in the OLS estimate is positively related to the cross-sectional effect, and the estimator is upwardly biased. And the hysteresis of the dependent variable in the fixed effect FE is negatively correlated with the random perturbation term, and the estimator is biased downward. If the first-order estimation coefficient of the lagged variable is between the estimate of fixed effect and the estimate of OLS, the system GMM model estimate is valid and reliable, as is the empirical result. In addition, using non-income share as another indicator of income diversification, the results show that the basic conclusions of this paper are still valid.

\section{Conclusion}

To carry out targeted differential regulation, the regulatory authorities need to combine the actual situation of China's banking industry with diversified performance of different types of banks in the economy upstream and downstream, constructing a counter-cyclical capital regulatory framework that is conducive to financial stability in order to avoid bank debt hedging and counter-cyclical policy objectives. Second, while encouraging financial innovation and restructuring of the business structure, the regulatory authorities should also pay attention to the impact of income diversification on the cyclical impact of capital buffers; 
only in this way we can prevent the blind expansion of banks from carrying out intermediary business and producing procyclical behaviors of the capital buffer. In the context of financial liberalization and financial globalization, the bank's business structure is also undergoing profound changes, and resulting more complicated influences on capital buffers in the change of bank income structure. In the face of banks with low capital adequacy ratios, regulators should encourage them to develop intermediary business and focus on raising their own capital adequacy levels.

\section{References}

[1] Shim, J. (2013) Bank Capital Buffer and Portfolio Risk: The Influence of Business Cycle and Revenue Diversification. Journal of Banking and Finance, 37, 761-772.

[2] Ayuso, J., Pérez, D. and Saurina, J. (2002) Are Capital Buffers Pro-Cyclical?: Evidence from Spanish Panel Data. Journal of Financial Intermediation, 13, 249-264. https://doi.org/10.1016/S1042-9573(03)00044-5

[3] Jiang, H., Luo, G.J. and Zhu, T. (2012) The Counter-Cyclical Research on the Capital Buffering of Chinese Listed Banks: 1998-2011. Finance Research, No. 9, 34-47.

[4] Rime, B. (2001) Capital Requirements and Bank Behaviour: Empirical Evidence for Switzerland. Journal of Banking and Finance, 25, 789-805. https://doi.org/10.1016/S0378-4266(00)00105-9

[5] Zhou, K.G. and Li, L. (2011) Effect of Diversification of Income Structure of Chinese Commercial Banks on Bank Risks. International Finance Research, No. 5.

\section{Scientific Research Publishing}

Submit or recommend next manuscript to SCIRP and we will provide best service for you:

Accepting pre-submission inquiries through Email, Facebook, LinkedIn, Twitter, etc. A wide selection of journals (inclusive of 9 subjects, more than 200 journals) Providing 24-hour high-quality service User-friendly online submission system Fair and swift peer-review system Efficient typesetting and proofreading procedure Display of the result of downloads and visits, as well as the number of cited articles Maximum dissemination of your research work

Submit your manuscript at: http://papersubmission.scirp.org/ Or contact ojbm@scirp.org 